\title{
Evaluation of Diagnostic Performance of BD Max EBP Assay in Patients with Diarrheal Illness.
}

\section{Ozlem KOYUNCU OZYURT}

Akdeniz Universitesi Tip Fakultesi https://orcid.org/0000-0003-1260-0671

\section{Imran SAGLIK}

Bursa Uludag University: Bursa Uludag Universitesi

\section{Betil OZHAK ( $\square$ ozlemozyurt@akdeniz.edu.tr)}

Department of Medical Microbiology, Faculty of Medicine, University of Akdeniz

\section{Derya MUTLU}

Akdeniz Universitesi Tip Fakultesi

\section{Belkıs LEVENT}

Special Pathogens Laboratory

\section{Levent DONMEZ}

Akdeniz Universitesi Tip Fakultesi

\section{Filiz GUNSEREN}

Akdeniz Universitesi Tip Fakultesi

\section{Gozde ONGUT}

Akdeniz Universitesi Tip Fakultesi

\section{Dilek COLAK}

Akdeniz Universitesi Tip Fakultesi

\section{Dilara OGUNC}

Akdeniz Universitesi Tip Fakultesi

\section{Research}

Keywords: Bacterial enteric pathogens, BD Max EBP Assay, PCR, Culture

Posted Date: March 2nd, 2021

DOI: https://doi.org/10.21203/rs.3.rs-258584/v1

License: (c) (i) This work is licensed under a Creative Commons Attribution 4.0 International License. Read Full License 


\section{Abstract}

Background: Detection of the etiological agents in patients with acute diarrhea is challenging due to a wide variety of pathogens. Detection and identification of the pathogens of acute diarrhea are important for both individual patient care and public health. The aim of this study is to evaluate the diagnostic performance of BD Max Enteric Bacterial Pathogens (EBP) PCR assay in patients with diarrheal illness.

Methods: Between 1 January 2014 and 31 May 2015, one thousand two hundred twenty four stool samples from pediatric or adult patients with diarrhea submitted for routine analysis of bacterial stool pathogens were included in the study. We compared the BD Max EBP PCR assay to culture for the detection of Salmonella spp., Shigella spp., Campylobacter jejuni, and Campylobacter coli and an EIA (Enzym Immun Assay) for Shiga toxins 1 and 2. Discordant results were adjudicated by either antigen detection methods or Film array GI (Gastro Intestinal) Panel. Coinfections were excluded. The chi-square test was used for comparisons of PPA and NPA.

Results: The PPA (positive percent agreement) values for the BD Max EBP assay was $100 \%$ and NPA (negative percent agreement) was between $98.0 \%-99.7 \%$, when compared with culture and EIA. After discrepant analysis, the PPA values for the BD Max EBP assay was $100 \%$ and NPA was between $99.5 \%-100 \%$.

Conclusion: The BD Max EBP assay showed a high correlation rate with conventional and molecular methods for the detection of stool pathogens.

\section{Introduction}

Infectious diarrheal diseases cause substantial morbidity and mortality worldwide. A wide variety of pathogens lead to infectious diarrhea, which makes the diagnosis of bacterial pathogens particularly challenging given the large amounts of background normal gastrointestinal flora [1, 2].

Viral agents such as the noroviruses are responsible for most of the acute infectious diarrhea, while bacteria are responsible for most cases with more aggresive and inflamatory diarrhea. [3] Salmonella, Campylobacter, Shigella, and Shiga toxin-producing Escherichia coli (STEC) are the most common diarrheagenic bacteria and routine stool culture is designed to detect these pathogens in most laboratories [4].

Detection and identification of the pathogens of acute diarrhea are important for both individual patient care and public health investigation. Furthermore, some infectious diarrheal pathogens can lead to longterm complications such as Hemolytic uremic syndrome and Guillain-Barre syndrome. [5].

Conventional stool culture is the gold standard for the diagnosis of bacterial gastroenteritis [6]. On the other hand stool cultures are either insensitive or labor intensive with long turnaround time. For the diagnosis of bacterial diarrhea, a wide variety of culture protocols involving multiple selective media and reagents are available in the microbiological laboratory $[1,7]$.However, the use of antibiotics affects the 
culture result and frequently causes low yield for identification of enteropathogens [7].Molecular methods can increase sensitivity and specificity compared to stool culture [8].

\section{Materials And Methods}

The aim of this study is to evaluate the diagnostic performance of BD Max Enteric Bacterial Pathogens (EBP), assay which is a Polymerase Chain Reaction (PCR) test, in patients with diarrheal illness in Turkey. Between 1 January 2014 and 31 May 2015 in Akdeniz University in Antalya, one thousand two hundred twenty four stool samples from pediatric or adult patients with diarrhea submitted for routine analysis of bacterial stool pathogens were included in the study. Duplicate specimens from the same patient were not enrolled. We compared the BD Max EBP assay to culture for the detection of Salmonella spp., Shigella spp., Campylobacter jejuni, and Campylobacter coli and an Enzym Immun Assay (EIA) for Shiga toxins 1 and 2. Discordant results were adjudicated by either antigen detection methods or Film array GI (Gastro Intestinal) Panel.

Culture and Enzyme Immunoassay (EIA): Fresh stool specimens were inoculated onto Mac Conkey agar, Xylose Lysine Deoxycholate (XLD) Agar for Salmonella and Shigella, and incubated at $37^{\circ} \mathrm{C}$ for 24 hours in an aerobic incubator. Lactose, xylose nonfermenting colonies with or without black centers on these media were screened phenotypically on triple sugar iron agar, motility medium, urea agar, Simmon's citrate agar and lysine iron agar. Suspected colonies were tested with Wellcolex ${ }^{\text {TM }}$ Color Salmonella Rapid Latex Agglutination Test Kit and Wellcolex ${ }^{\mathrm{TM}}$ Color Shigella (ThermoFisher, UK).

E. coli Shiga toxin was detected using by EIA (ProSpecT Shiga Toxin E. coli Microplate Assay, Remel, UK), according to the manufacturer's instructions.

Screening for Campylobacter spp. in stool was performed with Campylobacter selective agar (Becton, Dickinson and Company, USA) and incubated under microaerobic condition at $42^{\circ} \mathrm{C}$ for 5 days. Suspected colonies were identified by Gram stain examination of the colony along with oxidase test and Matrix Associated Laser Desorption Ionization Time of Flight Mass Spectrometry (MALDI-TOF MS).

BD Max EBP automated PCR: The BD Max EBP is a multiplex nucleic acid amplification assay which detects DNA from Campylobacter spp. (jejuni and coli), Salmonella spp., Shigella spp./Enteroinvasive E. coli (EIEC), Shiga toxin1(stx1)/Shiga toxin2(stx2) genes in stool specimens with the BD Max system less than three hours. (BD Diagnostics, Baltimore, MD, USA) (Harrington). The BD MAX ${ }^{\mathrm{m} M}$ System is a fullyautomated, closed system which allows for simultaneous processing of up to 24 individual tests. Fresh stool samples were tested daily with the BD Max EBP assay, according to the manufacturer's instructions.

We accepted conventional culture as the reference method for the detection of Shigella spp., Campylobacter spp and Salmonella spp. and EIA as the reference method for the detection of Shiga toxins for the calculation of Negative percent agreement (NPA) and Positive percent agreement (PPA) of BD Max EBP assay. 
In addition, BD Max EBP assay positive and conventional method negative results were adjudicated by either antigen detection methods or Film array GI Panel.

Stool samples with discordant results between Campylobacter culture and the BD Max EBP assay were tested by using an enzyme immunoassay (RIDASCREEN ${ }^{\circledR}$, Campylobacter, r-biopharm, Germany) according to the manufacturer's instructions. Samples that gave different results between the BD MAX EBP assay and Campylobacter EIA were subject to FilmArray Gastrointestinal (GI) Panel (BioFire- BioMeriux, France).

Samples with discordant results between Salmonella and Shigella culture or Shiga toxin EIA and the BD Max EBP assay were tested by FilmArray GI Panel following the manufacturer's instructions.

\section{Statistics}

PPA and NPA and their 95\% confidence intervals were calculated, as reported previously [9].

\section{Results}

One thousand two hundred twenty four stool samples were included in the study, 46 of which were excluded due to inhibition by BD Max EBP assay.

Culture and Shiga toxin EIA results: 14 (1.19\%) specimens were positive for Campylobacterspp, 22 (1.87\%) were positive for Salmonella spp. and two (0.17\%) were positive for Shigella/EIEC by culture. $21(1.78 \%)$ were positive for Shiga toxins by EIA. These were also positive with BD Max EBP assay. Coinfection was not detected by culture. The positivity rate of investigated pathogens was $5.01 \%(59 / 1178)$ by culture and EIA.

Of the 1178 samples, 30 had Salmonella spp., 6 had Shigella / EIEC, 37 had Campylobacter spp., and 38 had Shiga-like toxin genes (stx1 and / or stx2) by BD Max EBP assay. In addition, BD Max EBP assay identified coinfections in two samples (in one sample Salmonella + Shiga-like toxin genes and in another Campylobacter+Shiga-like toxin genes).

When coinfections were excluded, the NPA of the BD Max EBP assay was 99.3\% for Salmonella spp., 99.7 $\%$ for Shigella / EIEC, and $98.0 \%$ for Campylobacter spp. when compared with culture. NPA was $98.5 \%$ for Shiga toxins using EIA as a reference method. PPA was $100 \%$ for all targets (Table 1 ). 
Table 1

Performance of BD Max EBP assay when compared with the reference method (Culture and EIA)

\begin{tabular}{|c|c|c|c|c|c|c|c|}
\hline \multirow{3}{*}{ Target type } & \multicolumn{4}{|c|}{$\begin{array}{l}\text { No. of pathogens with BD Max EBP result } \\
\text { with reference to culture/EIA }\end{array}$} & \multirow{3}{*}{$\begin{array}{l}\text { Total } \\
\text { number } \\
\text { of } \\
\text { samples }\end{array}$} & \multirow{3}{*}{$\begin{array}{l}\text { PPA (95\% } \\
\text { confidence } \\
\text { interval) }\end{array}$} & \multirow{3}{*}{$\begin{array}{l}\text { NPA }(95 \% \\
\text { confidence } \\
\text { interval) }\end{array}$} \\
\hline & True & False & False & True & & & \\
\hline & Positive & Negative & Positive & Negative & & & \\
\hline Salmonella & 22 & 0 & 8 & 1146 & 1176 & 100 & $\begin{array}{l}99,31 \\
(98,83- \\
99,78)\end{array}$ \\
\hline Shigella/EIEC & 2 & 0 & 4 & 1170 & 1176 & 100 & $\begin{array}{l}99,66 \\
(99,33- \\
99,99)\end{array}$ \\
\hline Shiga toxins & 21 & 0 & 17 & 1138 & 1176 & 100 & $\begin{array}{l}98,53 \\
(97,84- \\
99,22)\end{array}$ \\
\hline Campylobacter & 14 & 0 & 23 & 1139 & 1176 & 100 & $\begin{array}{l}98,02 \\
(97,22- \\
98,82)\end{array}$ \\
\hline
\end{tabular}

Note: Coinfections were excluded in two samples

Results after discrepant analysis: Campylobacterspp. was isolated from culture in 14 out of 37 samples that were positive by BD Max EBP assay. In 9 out of 23 samples that were found to be incompatible by BD Max EBP assay and culture, the enzyme immunoassay (RIDASCREEN® Campylobacter, r-biopharm, Germany) was found to be positive. The remaining 14 discordant samples were studied with FilmArray GI Panel and Campylobacterspp. was positive in 10 samples. NPA was found as $99.7 \%$ for Campylobacter spp.

Discrepant results between culture or EIA and the BD Max EBP assay for Salmonella spp., Shigella spp., and Shiga-like toxin genes (stx 1 and/or st $\times 2$ ) were tested by using FilmArray GI Panel. The NPA of the BD Max EBP assay was $99.6 \%$ for Salmonella, $100 \%$ for Shigella / EIEC, and 99.5\% for Shiga toxin.

After analysis of discrepant results, use of BD Max EBP assay identified an additional 37 pathogens, thereby increasing the frequency to $8.2 \%$ (96/1176), when coinfections were excluded (Table 2). 
Table 2

Performance of BD Max EBP assay when compared with EIA and Film Array GI panel

\begin{tabular}{|c|c|c|c|c|c|c|c|}
\hline \multirow{3}{*}{ Target type } & \multicolumn{4}{|c|}{$\begin{array}{l}\text { No. of pathogens with BD Max EBP result } \\
\text { with reference to EIA and Biofire Film Array } \\
\text { GI Panel }\end{array}$} & \multirow{3}{*}{$\begin{array}{l}\text { Total } \\
\text { number } \\
\text { of } \\
\text { samples }\end{array}$} & \multirow[t]{3}{*}{$\begin{array}{l}\text { PPA }(95 \% \\
\text { confidence } \\
\text { interval) }\end{array}$} & \multirow[t]{3}{*}{$\begin{array}{l}\text { NPA }(95 \% \\
\text { confidence } \\
\text { interval) }\end{array}$} \\
\hline & True & False & False & True & & & \\
\hline & Positive & Negative & Positive & Negative & & & \\
\hline Salmonella & 25 & 0 & 5 & 1146 & 1176 & 100 & $\begin{array}{l}99,57 \\
(99,19- \\
99,94)\end{array}$ \\
\hline Shigella/EIEC & 6 & 0 & 0 & 1170 & 1176 & 100 & 100 \\
\hline Shiga toxins & 32 & 0 & 6 & 1138 & 1176 & 100 & $\begin{array}{l}99,48 \\
(99,06- \\
99,89)\end{array}$ \\
\hline Campylobacter & 33 & 0 & 4 & 1139 & 1176 & 100 & $\begin{array}{l}99,65 \\
(99,31- \\
99,99)\end{array}$ \\
\hline
\end{tabular}

Note: Coinfections were excluded in two samples

When the samples with coinfection were examined, there was no growth in culture and ElA tests results were negative. When these samples were studied with FilmArray GI Panel, Salmonella and Shiga-like toxin genes were found to be negative in one sample and only Campylobacter gene was positive in another sample with Campylobacter+ Shiga-like toxin genes.

\section{Discussion}

Detection of the etiological agents in patients with acute diarrhea is important for appropriate therapy and public health interventions. Culture remain the method of choice for diagnosis of bacterial enteritis. On the other hand, nucleic acid amplification tests offer rapid results and markedly improve the detection and identification of stool pathogens. The use of United States (US) Food and Drug Administration (FDA) approved culture-independent diagnostics in addition to traditional methods is supported by recent research [10].

Harrington et al conducted a multicenter evaluation of the BD Max EBP assay in comparison to culture for the detection of Salmonella spp., Shigella spp., Campylobacter jejuni, and Campylobacter coli and an EIA for Shiga toxins 1 and 2 with stool culture for fresh and preserved stool specimen. Following discrepant analysis, PPA and NPA values were $97.3 \%$ and $99.8 \%$ for Salmonella spp., $99.2 \%$ and $100 \%$ for Shigella spp., $97.5 \%$ and $99.0 \%$ for $C$.jejuni and $C$. coli, and $100 \%$ and $99.7 \%$ for Shiga toxins, respectively. They concluded that, the BD Max EBP assay with superior sensitivity compared to conventional methods and excellent specificity, may improve the detection of bacterial stool pathogens and time to reporting of results [9]. 
In a prospective study including 971 stool samples, the PPA of the BD MAX EBP assay and stool culture or enzyme immunoassay was 0.97 for Campylobacter spp., 0.75 for Salmonella spp., 1.00 for Shigella spp., and 0.88 for Shiga toxins. Furthermore, a NPA of 0.98 for Campylobacter spp., 0.99 for Salmonella spp., 0.99 for Shigella spp., and 0.99 for Shiga toxins has been demonstrated. They found that the use of the BD MAX EBP increased the overall detection rate from $5.26 \%$ to $8.06 \%$. Their study highlighted the superior detection rate of molecular assays compared to conventional diagnostic procedures [1].

Biswas et al evaluated the diagnostic accuracy and laboratory turnaround time of three molecular assays. When the prospective samples were evaluated, the sensitivity and specificity of BD MAX EBP assay for Salmonella spp., Shigella spp., and Campylobacter spp. were found to be $99.7-100 \%$ [11].

Anderson et al investigated the performance of the BD MAX EBP in preserved stool specimens that were artificially spiked with pathogen strains at different concentrations. The EBP panel demonstrated superior sensitivity and reliably detected Salmonella, EHEC 0157, Shigella, and Campylobacter at concentrations 1to $2-\log 10$ lower than those needed for culture detection [2].

Mortensen et al evaluated 86 stool samples with culture and BD Max EBP. Approximately $20 \%$ of cultures required additional process steps to exclude potential pathogens. Negative result reporting time with conventional culture was found to be approximately $41-54$ hours [12].

In our study, BD Max EBP assay showed excellent performance for the detection of Salmonella spp., Shigella spp., Campylobacter spp. and Shiga toxins. The NPA of BD MAX EBP in our study was similar to previous reports. Since we did not have a BD MAX EBP negative but the reference test positive sample, PPA of BD MAX EBP in our study was slightly higher than previous studies. The reasons for this difference may be due to interlaboratory technical variance, specimen transport and processing practices such as unemployment of enrichment broth.

This is a single center, laboratory-based, prospective study with a high number of samples. The clinical features of patients were not included. The study was done only in fresh stool samples but not Cary Blairpreserved specimens.

\section{Conclusion}

We concluded that, the BD Max EBP showed a high correlation rate with conventional and molecular methods for the detection of stool pathogens. In addition, our detection rates increased with BD Max EBP which has high PPV and NPV. On the other hand, BD Max EBP assay detect DNA and not necessarily viable organisms which may lead to increased appreciation of asymptomatic infections and prolonged shedding. For this reason the results should be interpreted with consideration of clinical information.

\section{Abbreviations}

STEC: Shiga toxin-producing Escherichiacoli 
EBP: Enteric Bacterial Pathogens

PCR: Polymerase Chain Reaction

EIA: Enzym Immun Assay

Gl: Gastro Intestinal

XLD: Xylose Lysine Deoxycholate

MALDI-TOF MS: Matrix Associated Laser Desorption Ionization Time of Flight Mass Spectrometry

EIEC: Entero Invasive E. coli

(Stx1) / (Stx2): Shiga toxin1/Shiga toxin2

NPA: Negative percent agreement

PPA: Positive percent agreement

US FDA: United States Food and Drug Administration

\section{Declarations}

Ethics approval and consent to participate:

This study was approved by the Akdeniz University School of Medicine Ethical Committee of Clinical Research (Decision number: 471).

Consent for publication:

Not applicable

\section{Availability of data and materials:}

All data generated or analyzed during this study are included in this published manuscript.

Competing interests:

None of the authors have any competing interests in the manuscript.

Acknowledgements:

Not applicable.

\section{Funding:}

Not applicable. 


\section{Authors' contributions:}

OKO, IS, BO, GO, DO and DC designed the study and wrote the manuscript; OKO, DO, LD and BO analyzed data; FG and OKO,collected samples, clinical data, and contributed to the manuscript preparation; LD and OKO applied the statistics; OKO, IS, BL performed the experiments, GO, DO, BO and FG made critical revisions to the manuscript. All authors read and approved the final manuscript.

\section{References}

1. Knabl L, Grutsch I, Orth-Höller D. Comparison of the BD MAX Enteric Bacterial panel assay with conventional diagnostic procedures in diarrheal stool samples. Eur J Clin Microbiol Infect Dis. 2016;35:131-6.

2. Anderson NW, Buchan BW, Ledeboer NA. Comparison of the BDMAX enteric bacterial panel to routine culture methods for detection of Campylobacter, enterohemorrhagic Escherichia coli (0157), Salmonella, and Shigella isolates in preserved stool specimens. J Clin Microbiol. 2014;52:1222-4.

3. Dryden MS, Gabb RJ, Wright SK. Empirical treatment of severe acute community-acquired gastroenteritis with ciprofloxacin. Clin Infect Dis. 1996;22:1019-25.

4. Shane AL, Mody RK, Crump JA, Tarr PI, Steiner TS, Kotloff K, et al. Infectious Diseases Society of America Clinical Practice Guidelines for the Diagnosis and Management of Infectious Diarrhea. Clin Infect Dis. 2017;65(12):e45-e80.

5. Guerrant RL, Van Gilder T, Steiner TS, Thielman NM, Slutsker L, Griffin PM, et al. Infectious Diseases Society of America. Practice guidelines for the management of infectious diarrhea. Clin Infect Dis. 2001;32(3):331-5.

6. Humphries RM, Linscott AJ. Practical Guidance for Clinical Microbiology Laboratories: Diagnosis of Bacterial Gastroenteritis. Clin Microbiol Rev. 2015;28(1):3-31.

7. Operario DJ, Houpt E. Defining the causes of diarrhea: novel approaches. Curr Opin Infect Dis. 2011;24(5):464-71.

8. Ozyurt OK, Bertocco ALFVB, Pereira LAB, Jimenes LP, Yazisiz H, Ozhak B, et al. Detection of Salmonella, Campylobacter, Shiga toxin-producing E. coli and Shigella/EIEC by culture and a multiplex PCR panel in pediatric patients with acute diarrheal illness. Journal of Laboratory Medicine 2019;43:211-5. https://www.degruyter.com/view/journals/labm/43/4/article-p211.xml

9. Harrington SM, Buchan BW, Doern C, Fader R, Ferraro MJ, Pillai DR, et al. Multicenter evaluation of the BD max enteric bacterial panel PCR assay for rapid detection of Salmonella spp., Shigella spp., Campylobacter spp. (C. jejuni and C. coli), and Shiga toxin 1 and 2 genes. J Clin Microbiol 2015;53(5):1639-47.

10. Riddle MS, DuPont HL, Connor BA. ACG Clinical Guideline: Diagnosis, Treatment, and Prevention of Acute Diarrheal Infections in Adults. Am J Gastroenterol 2016;111:602-22.

11. Biswas JS, Al-Ali A, Rajput P, Smith D, Goldenberg SD. A paralel diagnostic accuracy study of three molecular panels for the detection of bacterial Eur J Clin Microbiol Infect Dis 2011;33(11):2075-81. 
12. Mortensen JE, Ventrola $C$, Hanna S, Walter A. Comparison of time-motion analysis of conventional stool culture and the BD MAX ${ }^{\mathrm{TM}}$ Enteric Bacterial Panel (EBP). BMC Clin Pathol 2015;15:9. 